\title{
UV radiation induced DNA damage in marine viruses along a latitudinal gradient in the southeastern Pacific Ocean
}

\author{
Steven W. Wilhelm ${ }^{1, *}$, Wade H. Jeffrey ${ }^{2}$, Amanda L. Dean ${ }^{1}$, Jarah Meador ${ }^{3}$, \\ J. Dean Pakulski ${ }^{2}$, David L. Mitchell ${ }^{3}$ \\ ${ }^{1}$ Department of Microbiology, The University of Tennessee, 1414 West Cumberland, Knoxville, Tennessee 37996, USA \\ ${ }^{2}$ Center for Environmental Diagnostics, The University of West Florida, 11000 University Parkway, Pensacola, Florida 32514, USA \\ ${ }^{3}$ The University of Texas M.D. Anderson Cancer Center, Department of Carcinogenesis, Park Road 1, Smithville, \\ Texas 78957, USA
}

\begin{abstract}
UV radiation induced DNA damage (inferred from cyclobutane pyrimidine dimers, CPDs) in native marine virus communities was examined at 12 locations along a latitudinal transect from $41^{\circ} \mathrm{S}$ to $3^{\circ} \mathrm{N}$ in the southeastern Pacific Ocean. Surface waters were collected prior to sunrise each day and placed in UV transparent incubators kept at in situ seawater temperatures. A replicate treatment was prefiltered through a $0.2 \mu \mathrm{m}$ filter to remove microbial host cells. Both treatments were exposed to ambient solar radiation until approximately $1 \mathrm{~h}$ before sunset. At the end of the day, the virus fraction was collected from each sample by filtration and concentration. DNA damage was determined in each fraction and compared to DNA damage in pre-dawn samples as well as DNA dosimeters exposed to an entire solar day's influence. CPDs in dosimeters and integrated solar irradiance were very highly correlated, as was DNA damage in the pre-sunrise virus community and latitude. A reduction in host cell abundance resulted in no consistent pattern or change in the CPD induction of virus particles, suggesting minimal host mediated repair in this natural virus community. The low daily induction of damage in virus incubations combined with the high residual damage suggests that the sunrise damage levels were the result of DNA damage accumulation over numerous days, indicating a long residence time for virus particles in surface waters in this region.
\end{abstract}

KEY WORDS: Virus · DNA damage $\cdot$ Cyclobutane pyrimidine dimers $\cdot$ Southeastern Pacific Ocean Marine microbiology

Resale or republication not permitted without written consent of the publisher

\section{INTRODUCTION}

During the last decade, it has become apparent that viral activity has a significant impact on the biogeochemistry as well as microbial community structure and dynamics of marine environments (Fuhrman 1999, Wilhelm \& Suttle 1999, Wommack \& Colwell 2000). As such, aquatic microbial ecologists have endeavored to determine the factors and processes that influence the persistence and activity of this pervasively distributed group of obligate pathogens. While a series of studies have demonstrated that several processes are involved

*Email: wilhelm@utk.edu in the removal of viral particles from the water column, such as grazing by protozoans (e.g. Gonzalez \& Suttle 1993), perhaps the most significant stressor on viral communities is exposure to solar radiation (reviewed in Jeffrey et al. 2000).

Owing to their 'simple' construction, marine viral particles, which are comprised mainly of protein and nucleic acids, have been hypothesized to be sensitive to ambient water column doses of sunlight. Studies in recent years have confirmed this, and demonstrated that naturally occurring UV radiation represents the most significant factor implicated in the destruction of 
viral infectivity in surface waters (Suttle \& Chen 1992, Wommack et al. 1996, Noble \& Fuhrman 1997, Garza \& Suttle 1998, Wilhelm et al. 1998a, 2002). In fact, measured destruction rates of viral infectivity are so high that scientists had been left with a paradox concerning their existence: while estimates of UV-mediated destruction predicted viral clearance rates that should sterilize the water column on a daily basis, high titers of infectious viral particles continued to persist in these environments (Suttle et al. 1993). This problem was partially resolved by the realization that some UVmediated damage (as inferred from the formation of cyclobutane pyrimidine dimers, CPDs) could be repaired on a daily scale by host-cell-mediated repair mechanisms (Weinbauer et al. 1997).

Early attempts to understand the persistence of viruses under significant UV pressures suggested that the temporal and spatial distribution of viral production, in consideration of water column mixing, were important (Murray \& Jackson 1993). In part, the depth-dependent decay of viral infectivity (relative to the destruction of viral particles; Wommack et al. 1996) suggested an imbalance. If viral particles were destroyed at a lower rate than viral infectivity was lost from a community, and production of viral infectivity was a direct result of new viral particles, then the ocean (in theory) would eventually fill up with noninfectious viral particles (Wilhelm et al. 1998a). This problem was partially offset by the observation that photoreactivation (Dulbecco 1949, 1950) could restore infectivity in up to $78 \%$ of the damaged marine viral particles in the Gulf of Mexico (Weinbauer et al. 1997). Moreover, subsequent lab studies demonstrated that the range of viral DNA damage observed in samples collected from the Gulf of Mexico was sufficiently low that more than $50 \%$ of the viral population should be considered infective if photoreactivation was allowed to occur during the solar day (Wilhelm et al. 1998b). Further observations regarding both photoreactivation and light-independent ('dark') repair mechanisms have supported this notion (Kellogg \& Paul 2002).

Two themes that persist through the above studies are the limited spatial extent of the examinations and the assumption that viral damage, produced during the solar day, can be in part repaired through the dark hours so that a community of infected hosts could be established prior to the next day's solar exposure. As such, persistence of individual particles in the UVexposed surface waters through multiple solar cycles would not be expected. The current study addresses both of these issues as we have collected natural viral communities along a transect over $40^{\circ}$ in latitude in the southeastern Pacific Ocean (approximately $5000 \mathrm{~km}$ ). We entered this study with the hypothesis that a reduc- tion in the abundance of host cells would permit us to determine the gross rate of DNA damage accumulation, and that a comparison of this rate to the net rate of accumulation (i.e. viral DNA damage accumulation in the presence of hosts) would allow us to infer the rate of host-mediated DNA repair.

\section{MATERIALS AND METHODS}

Station locations. Sample collections and experiments were conducted aboard the RVIB 'Nathaniel B. Palmer' from 24 June to 4 August 2000 along a transect originating at $41.18^{\circ} \mathrm{S}, 78.07^{\circ} \mathrm{W}$, and terminating at $4.05^{\circ} \mathrm{N}, 81.93^{\circ} \mathrm{W}$. Deck incubation experiments were conducted daily at intervals of ca. $4^{\circ}$ latitude (Fig. 1).

Irradiance measurements. Surface irradiance was measured continuously ( $1 \mathrm{~min}$ bin averaged intervals summed for total daily amounts) while underway using a mast mounted Biospherical Instruments GUV 511C radiometer. Daily integrated values for UVB (305 nm), UVA (380 nm) and photosynthetically active radiation (PAR, 400 to $700 \mathrm{~nm}$ ) were estimated by summation of 1 min measurement from local sunrise to local sunset over the cruise track.

Collection of natural virus communities. Three surface water samples (ca. 100 to $200 \mathrm{l}$ at 1 to $3 \mathrm{~m}$ depth) were collected each day prior to sunrise with a deployable pumping system. The first sample was placed in a UV transparent on-deck incubator (200 l tanks built of $1.25 \mathrm{~cm}$ thick UV transparent Plexiglas jacked by a second tank of similar construction with flowing seawater in the inner jacket space for temperature control) to allow for exposure to a complete solar day's irradiation (from sunrise until approximately $1 \mathrm{~h}$ before sunset), while the second sample was prefiltered through a $0.2 \mu \mathrm{m}$ nominal pore size, $142 \mathrm{~mm}$ diameter polycarbonate filter prior to placement into a parallel incubator. The third sample was used to collect the natural viral community and represents the pre-dawn concentration of DNA damage in the viruses. Samples were serially filtered through $0.6 \mu \mathrm{m}$ nominal pore size glass fiber filters (147 mm; Whatmann GFF) and a $0.2 \mu \mathrm{m}$ nominal pore size $142 \mathrm{~mm}$ diameter filters (Gelman) to remove zooplankton, phytoplankton and bacteria. The viruses remaining in the $0.2 \mu \mathrm{m}$ filtrate were concentrated ca. 500-fold using an Amicon M12 ProFlux ultrafiltration system equipped with an Amicon S10Y30 cartridge (Wilhelm \& Poorvin 2001). Similarly the on-deck samples were processed by ultrafiltration at the end of the solar day to collect the natural communities that were exposed with or without their hosts. Viral concentrates were immediately stored at $4^{\circ} \mathrm{C}$ and in the dark until they could be returned to the lab for processing. 
Purification of viral DNA and the determination of photoproduct concentrations. For the extraction of DNA, viruses in seawater concentrates were collected by centrifugation $(3 \mathrm{~h}$ at $104000 \times g)$. Viruses were resuspended in $1 \mathrm{ml}$ of sterile artificial seawater (ESAW; Harrison et al. 1980) and treated with DNase $\left(200\right.$ Kunitz U, $2 \mathrm{~h}$ at $37^{\circ} \mathrm{C}$ ). After the addition of $10 \mu \mathrm{l}$ of $0.5 \mathrm{M}$ EDTA (pH 8.0) and $10 \mu \mathrm{l}$ of SDS (10\% w/v), samples were heat treated $\left(95^{\circ} \mathrm{C}, 15 \mathrm{~min}\right)$ to release the DNA from the protein capsids. Viral DNA was purified by phenol-chloroform extraction and precipitated with ethanol (Sambrook et al. 1989). DNA was redissolved in autoclaved deionized-distilled water and DNA concentrations in subsamples were determined spectrophotometrically.

CPDs were quantified using a competitive radioimmunoassay (RIA) as described by Mitchell (1996). The antiserum for CPDs was raised against salmon testes DNA in $20 \mathrm{mM}$ acetophenone (a triplet sensitizer which promotes the production of CPDs but not 6-4 photoproducts) and irradiated with a UVB source (Westinghouse FS20, $75 \mathrm{~kJ} \mathrm{~m}^{-2}$ at $280 \mathrm{~nm}$ ). For the RIA, 2 to $5 \mathrm{mg}$ of heat denatured sample DNA was incubated with 5 to $10 \mathrm{pg}$ of poly $(\mathrm{dA})$ :poly $(\mathrm{dT})$ probe (the competitive ligand, labeled to $>5 \times 10^{8} \mathrm{cpm} \mathrm{gg}^{-1}$ by nick translation with ${ }^{32} \mathrm{P}$-dTTP) in a total volume of 1 $\mathrm{ml}$ buffer $(10 \mathrm{mM}$ Tris, $1 \mathrm{mM}$ EDTA, $150 \mathrm{mM} \mathrm{NaCl}$, $0.2 \%$ gelatin [Sigma] $\mathrm{pH} 7.8$ ). Antiserum was added to the reaction mixture at a dilution that yields 30 to $60 \%$ binding of the labeled ligand. After incubation for $3 \mathrm{~h}$ at $37^{\circ} \mathrm{C}$, the immune complex was precipitated with goat anti-rabbit immunoglobulin and a carrier serum from nonimmunized rabbits (both Calbiochem). After centrifugation, the supernatant was discarded, and the pellet was dissolved in tissue solubilizer (NCS, Amersham) before being transferred to a scintillation vial with Scintisafe 30\% LCS cocktail and counted in a Packard 1600TR scintillation counter. DNA photoproducts in the sample DNA are determined by the reduction in counts appearing in the pellet as a result of competition for antibody between the sample DNA and radiolabeled poly(dA):poly(dT) probe. Each assay was standardized with DNA of known photoproduct content. Samples were analyzed in duplicate.

Enumeration of bacteria and viruses. Viruses and bacteria were enumerated by epifluorescence microscopy of glutaraldehyde preserved $(2.5 \%$ final concentration, stored at $\left.4^{\circ} \mathrm{C}\right)$, SYBR Green 1 stained particles (Noble \& Fuhrman 1998). Replicate counts $(\mathrm{n}=2)$ were made within $4 \mathrm{wk}$ for each sample collected and the results expressed as the mean of those values.

DNA dosimeters. Dosimeters provide a means of measuring total damage to DNA without the influence of biological parameters, such as DNA repair or photoprotection. DNA dosimeters were constructed of

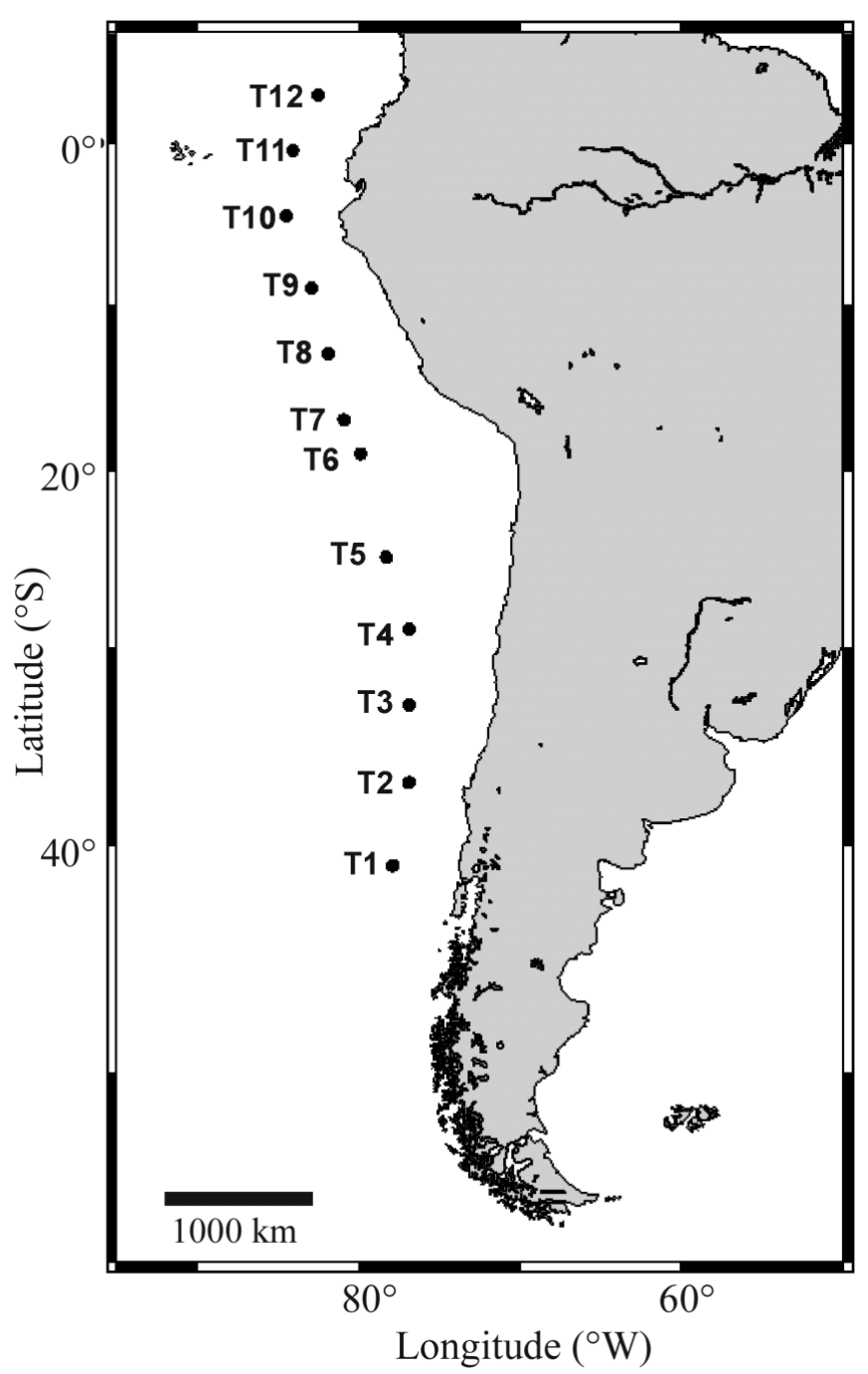

Fig. 1. Stations (T1 to T12) occupied in the Pacific Ocean along the western coast of South America

$0.1 \mathrm{mg} \mathrm{ml}^{-1}$ calf thymus DNA (ctDNA) in SSC buffer (0.15 M sodium chloride, $0.015 \mathrm{M}$ sodium citrate, $\mathrm{pH}$ 7.0 ) in a $3 \mathrm{ml}$ quartz tube (Quartz Scientific) sealed at each end with sterile silicon (Jeffrey et al. 1996). Dosimeters were placed directly in the UV transparent incubators along with each seawater sample. Following UV incubation, DNA solutions were removed from the quartz tubes and placed in $2 \mathrm{ml}$ Eppendorf tubes and frozen at $-70^{\circ} \mathrm{C}$ for later CPD analysis.

\section{RESULTS AND DISCUSSION}

To our knowledge, the results of this study represent the largest latitudinal gradient over which the biological effects of solar radiation (including UV radiation) on 


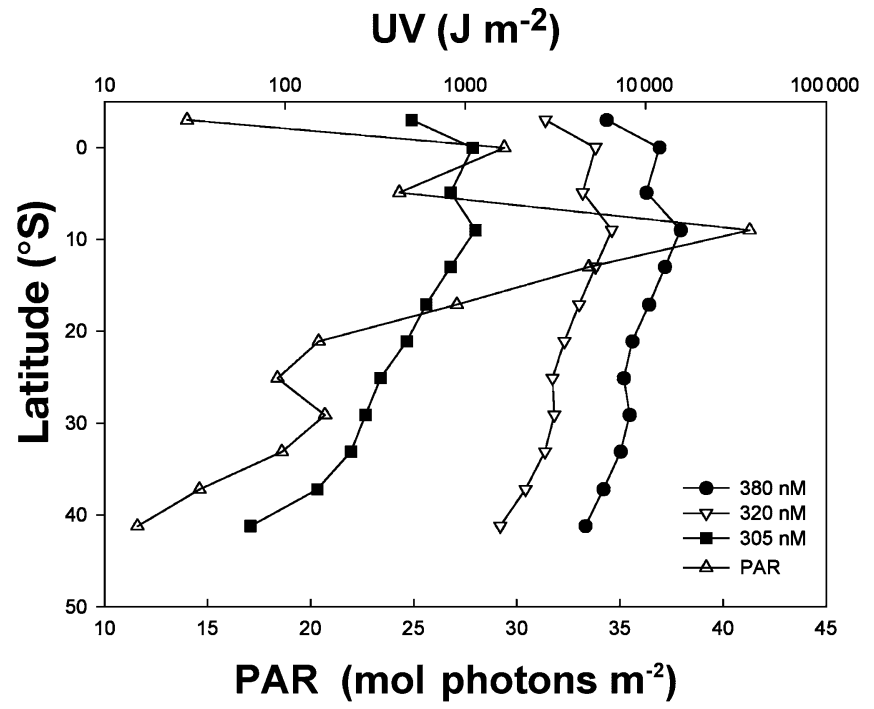

Fig. 2. Total daily irradiance estimates for total photosynthetically active radiation (PAR) as well as for discreet wavelengths $(305,320,380 \mathrm{nM})$ collected during this study. Daily estimates are plotted at the point of origin for each solar day as the incubations and measures were carried out as the ship was underway

marine viruses have ever been studied. The results of the study confirm that there is a significant latitudinal gradient in the effect of UV on marine viral communities. Although our intent was to quantify the magnitude of host-mediated DNA repair on natural viral communities, the approach we took provided inconclusive results. However, the results demonstrate that the residence time of viruses in marine surface waters may be significantly longer than we previously believed. Moreover, a comparison of the accumulation rates of DNA damage in the viruses relative to the ctDNA dosimeters suggests that some factor is influencing damage accumulation in the viral community. We consider these results below in the context of the physical geography and basin structure of the region, an area known for significant upwelling zones which potentially has a strong influence on microbial dynamics.

\section{Physical and biological characteristics of the transect}

As expected, the integrated daily dose of solar radiation increased during this transect, consistent with longer solar days and a decrease in the solar angle during this time of year (Fig. 2). Total doses, by wavelength, increased ca. 5-fold for $380 \mathrm{~nm}$ radiation to ca. 20 -fold for $305 \mathrm{~nm}$ radiation. As such, one would expect a significant increase in UV effects on the microbial communities as the transect progressed north. Surface concentrations of both bacterial and viral particles were larger at the southern end of the transect as well as for the area corresponding to the upwelling zones at the northern extreme (Fig. 3). In a parallel study (Pakulski et al. unpubl. data), similar results for chlorophyll ( $\mathrm{chl} \mathrm{a}$ ) concentrations in the water column were presented, resulting in a positive correlation between the bacterial abundance and chl a concentrations over the length of the transect.

Perhaps the most striking results of this study are the pre-dawn measures of DNA damage in the nat-
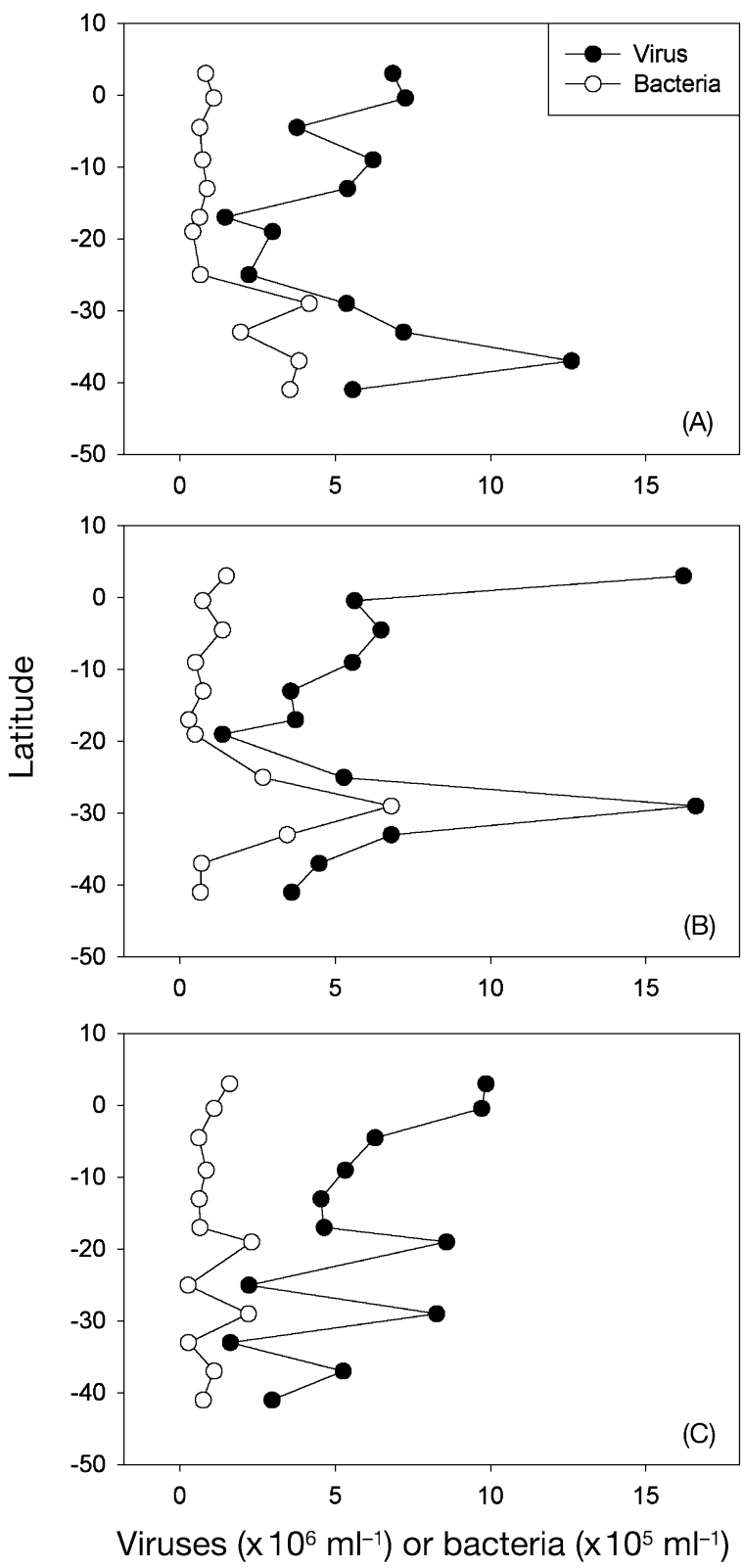

Fig. 3. Viral and bacterial abundance in the (A) pre-dawn, (B) post-exposure whole community and (C) post-exposure $0.2 \mu \mathrm{m}$ filtered communities. The daily integrated irradiance at $305 \mathrm{~nm}$ is plotted as the solid line for comparison 
ural viral communities (Fig. 4A). At all stations, CPD levels were high in samples collected prior to sunrise, ranging from ca. $250 \mathrm{Mb}^{-1}$ DNA in the southern stations to as high as $2000 \mathrm{Mb}^{-1}$ DNA in the equatorial regions of the transect. In our previous examinations of CPD formation in the natural marine viral community in the Gulf of Mexico, residual (early morning) CPDs were ca. 25 to $50 \mathrm{Mb}^{-1} \mathrm{DNA}$, with the highest value reaching only $180 \mathrm{CPDs} \mathrm{Mb}^{-1}$ DNA (Wilhelm et al. 1998b, Weinbauer et al. 1999). While some of this discrepancy may be due to an improvement in our analytical technique (Mitchell 1999, Jeffery \& Mitchell 2001), it is likely that differences in the microbial community and water column mixing also played a significant role. The South Pacific eastern boundary current off Peru is associated with an area of significant upwelling due to the physical oceanography of the system in this area. Deep water upwelled into this system advects slowly offshore, influencing the net transport of nutrients and small colloids (like viruses). Hutchins et al. (2002) recently demonstrated that this study area represented a coastal, Fe-limited HNLC zone. During a concurrent study to ours, data collected by Pakulski et al. (unpubl.) clearly support this in that they demonstrate significant concentrations of nitrate (10 to $20 \mu \mathrm{M})$ in the upwelling zone. Also, wind-driven mixing was minimal during our transect. These data suggest that significant upwelling activity was occurring during our cruise and may have influenced the surface residence time of the natural viral community, leading to the high residual DNA damage levels (see below).

\section{Latitudinal effects of solar influence on microbial populations}

Previously we have chosen to study the effects of UV on viruses due not only to the significance of viruses in marine biogeochemical cycles, but also due to viral morphology, consisting of mostly protein and nucleic acid; in marine systems, viruses represent natural dosimeters as they have no ability to repair themselves in the absence of their hosts. To examine the influence of DNA repair on the persistence of viruses in marine surface waters, we exposed populations with and without their hosts under the assumption that the difference in the accumulation of DNA damage in parallel exposures would be due to viral activity within the hosts, which by necessity would require some level of DNA repair. Using a $t$-test for correlated values (aka matched $t$-test; Andersen \& Finn 1996), we found no significant difference ( $p>$ 0.05 ) between the viral populations in any of the treatments, with only a significant difference $(\mathrm{p}>$ 0.10 ) for the bacterial abundances between the $t_{0}$ and the filtered sample at the end of the day (Fig. 3). The results suggest that there was no significant influence
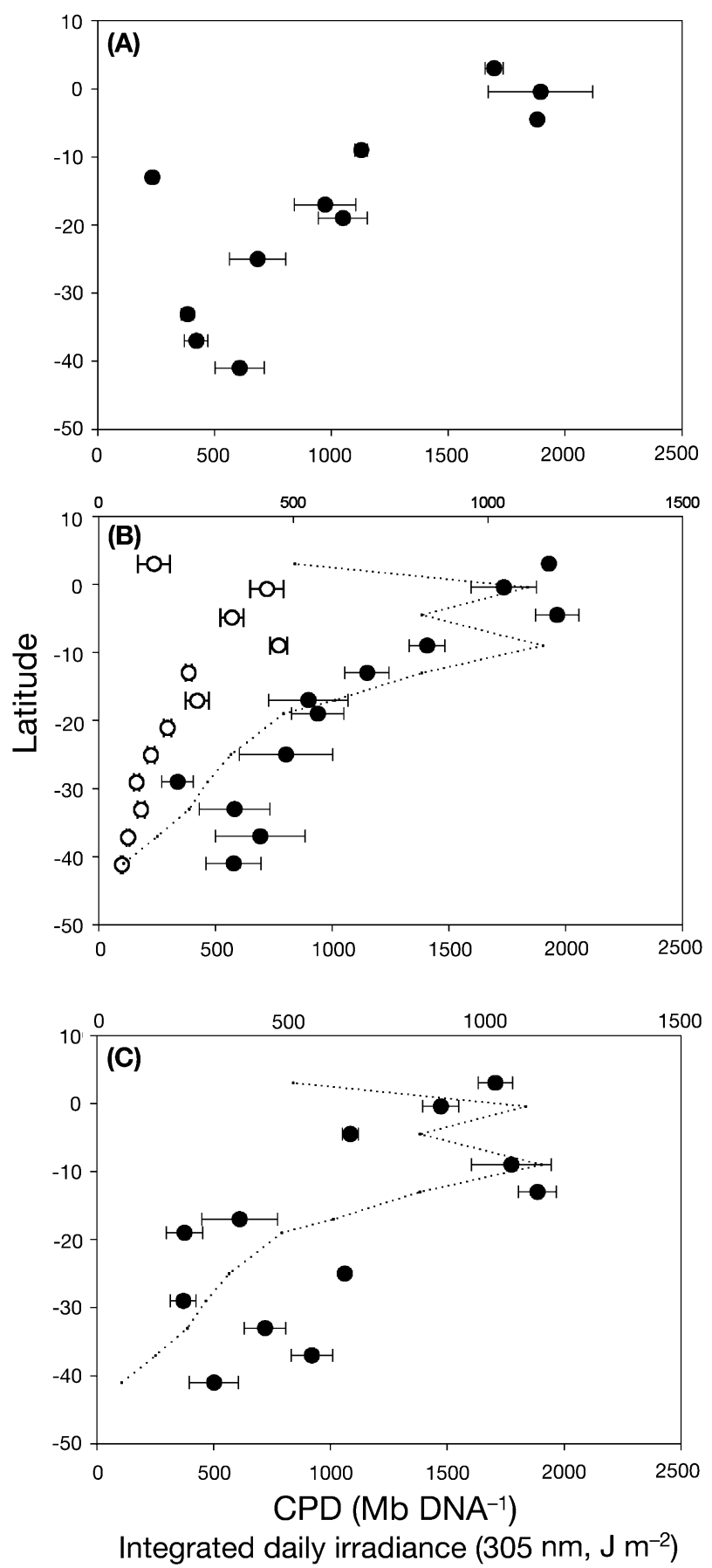

Fig. 4. Latitudinal effects on DNA damage (CPDs) in the natural viral community $(\bullet)$ from (A) pre-dawn, B) post-exposure whole community and (C) post-exposure $0.2 \mu \mathrm{m}$ filtered communities as well as for ctDNA dosimeters exposed to an entire solar day (Panel $\mathrm{B} ; \circ)$. The dotted line in Panels $\mathrm{B}$ and $\mathrm{C}$ represents the integrated daily irradiance of $305 \mathrm{~nm}$ light 

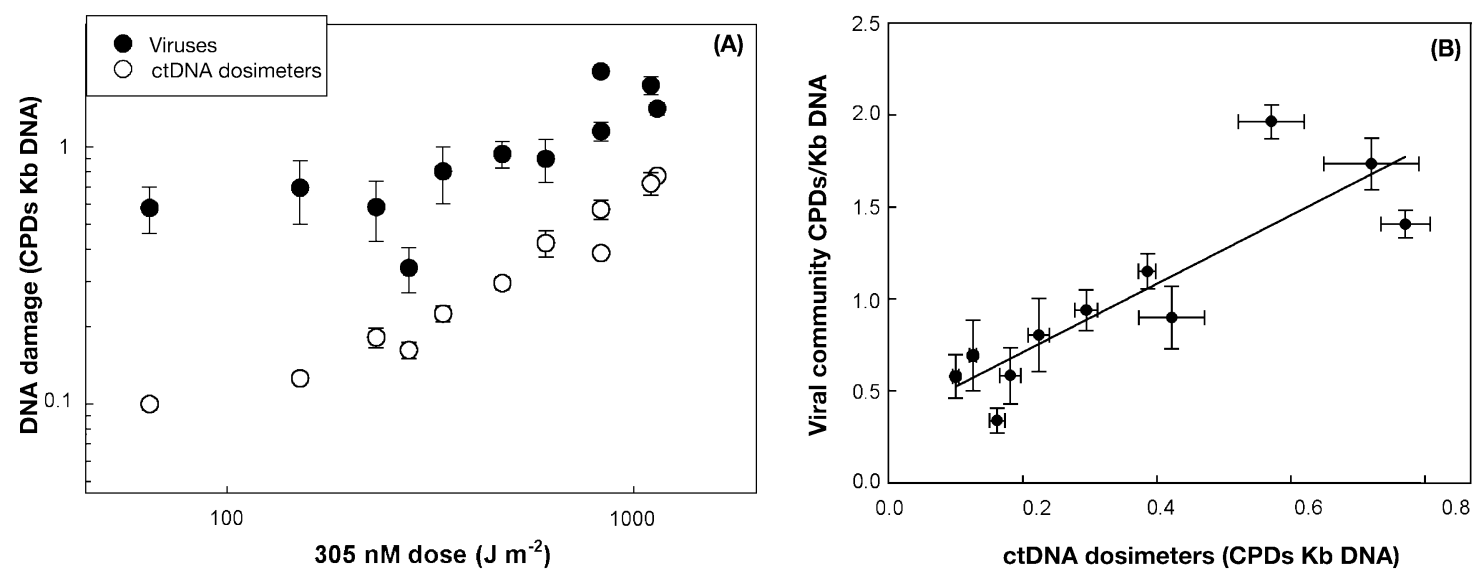

Fig. 5. Correlation between (A) DNA damage and UV (305 nm) dose and (B) the correlation of DNA photoproducts (CPDs) in ctDNA and the natural virus community

of the filtration on the abundance of viruses in the sample, and that the presence of viruses in the samples exposed for the entire solar day had no significant influence on the abundance of bacteria. The results also suggest that bacteria passing through the filters were able to repopulate the samples by the end of the solar day. As a result, the difference in the exposed treatments (filtered vs non-filtered) was confounded by the rapidly replenished bacterial community and suggests that we may not have been able to remove host-mediated repair by filtration. As such, future considerations may require the use of some bacteria-specific agents to reduce/remove their activity.

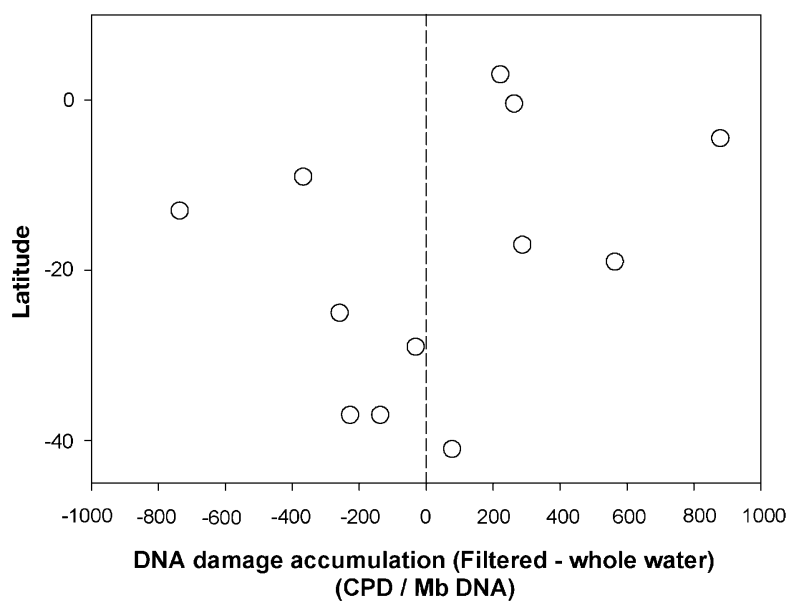

Fig. 6. Comparison of the difference in DNA damage in the viral size fractions between pre-dawn, unfiltered seawater (net DNA damage) and pre-dawn, $0.2 \mu \mathrm{m}$ filtered samples (gross DNA damage) after UV exposure of both sample types for an entire solar day. The difference in the 2 treatments should be a result of DNA repair and the production of new, undamaged viral particles by the marine bacterial community

\section{Latitudinal effects on DNA damage accumulation in marine viruses and dosimeters}

The concentration of DNA damage in viruses (CPDs $\left.=0.44\left[\mathrm{~J} \mathrm{~m}^{-2}{ }_{305 \mathrm{~nm}}\right]+1.81, \mathrm{r}=0.756\right)$ and ctDNA dosimeters (CPDs $\left.=0.75\left[\mathrm{~J} \mathrm{~m}^{-2}{ }_{305 \mathrm{~nm}}\right]+0.51, \mathrm{r}=0.961\right)$ at the termination of a single day's exposure increased as we headed north in correlation to the increase in $305 \mathrm{~nm}$ radiation (Fig. 5A). However, the relative accumulation of DNA damage in the ctDNA dosimeters was almost twice that of the accumulation of damage in the viruses $\left(\mathrm{CPDs}_{\text {viruses }}=1.86 \mathrm{CPDs}_{\mathrm{ctDNA}}+337, \mathrm{r}=0.869\right.$; Fig. 5B). This reduced accumulation rate is most likely a result of viral production by the small population of bacteria that pass through the $0.2 \mu \mathrm{m}$ filters (producing viruses with no DNA damage) combined with the presence of the protein coat which may provide some protection to the viral genomes relative to the naked ctDNA in the dosimeters.

By subtracting the rate of accumulation of DNA damage in the viral communities over a single day's exposure from the levels of CPDs seen in the pre-dawn samples, it is apparent that the viruses in this region would require several days of exposure in order to accumulate the significant amount of DNA damage that we see in this group in surface waters (Fig. 6). In the case of studies in the Gulf of Mexico (Weinbauer 1997, Wilhelm et al. 1998a,b), it was assumed that viral communities were mixed homogeneously through the upper mixed layer. As such, viruses would be exposed to different degrees of both damaging and photorepairing light. The results from those studies demonstrated that concentration of residual DNA damage from the previous day was low in pre-sunrise samples. In the current study, residual DNA damage is high in the pre-sunrise samples. Moreover, this amount of damage is higher than the total DNA damage that accumulates in the 
ctDNA dosimeters or the full day exposed viral communities from our incubations (ca. 2- to 10-fold in either case). As such, it appears that the viruses in the water column must have a residence time of several days in order for the community to accumulate this net amount of damage. In as much as these results re-establish the paradox of viral stability (as addressed in the 'Introduction'), they also suggest that the model systems available for laboratory studies (e.g. Noble \& Fuhrman 1997, Wilhelm et al. 1998a) may not sufficiently mimic the ecology of viruses in natural systems.

\section{CONCLUSIONS}

The western coasts of Peru and Chile (the area of our northernmost stations) are highlighted by an area of virtually year-round, persistent upwelling with shallow underlying suboxic waters (Minas \& Minas 1992, Morales et al. 1999). This results in a system in which primary producers experience low fluctuations in $\mathrm{Fe}$ availability that may regulate the accumulation of photosynthetic biomass (Hutchins et al. 2002). The results of the current study suggest that the residence time of viruses in these surface waters is significantly longer than previously believed. This conclusion is necessitated by the observation of CPD concentrations that exceed what could be accumulated in a single day. As such, it can be hypothesized that the persistent upwelling associated with this region strongly influences this residence time, perhaps by offsetting the vertical flux of free or particle-associated viruses. Due to Ekman transport, the water in upwelling regions advects offshore horizontally prior to being mixed into the water column (Hutchins et al. 1998). We thus hypothesize that the community of viruses we examined had been traveling along the surface for several days (since we were $>320 \mathrm{~km}$ from shore). Our previous reports comparing infectivity to CPD concentration (Wilhelm et al. 1998b) suggest that this viral community should still have been infectious and, as such, may be involved in driving the recycling of organic $\mathrm{Fe}$ in this region that would be critical to sustained microbial production (Wilhelm \& Suttle 2000, Hutchins et al. 2002). Although this remains an untested hypothesis, future observations of these viral communities will no doubt need to consider this when trying to resolve their ecology.

Acknowledgements. We thank the captain, crew and Raytheon Polar Services personnel of the RVIB 'Nathaniel B. Palmer' as well as Amy Baldwin and Karey Scott for their assistance at sea. We also thank Curtis Suttle for discussions regarding experimental design. This research was supported by National Science Foundation grants to W.H.J. (OPP 9827319) and S.W.W. (OCE 9977040).

\section{LITERATURE CITED}

Andersen TW, Finn JD (1996) The new statistical analysis of data. Springer-Verlag, New York

Dulbecco R (1949) Reactivation of ultraviolet inactivated bacteriophages by visible light. Nature 163:949-950

Dulbecco R (1950) Experiments on photoreactivation of bacteriophages inactivated with ultraviolet radiation. J Bacteriol 59:329-347

Fuhrman JA (1999) Marine viruses and their biogeochemical and ecological effects. Nature 399:541-548

Garza DR, Suttle CA (1998) The effect of cyanophages on the mortality of Synechococcus spp. and selection for UV resistant viral communities. Microb Ecol 36:281-292

Gonzalez JM, Suttle CA (1993) Grazing by marine nanoflagellates on viruses and virus-sized particles: ingestion and digestion. Mar Ecol Prog Ser 94:1-10

Harrison P, Waters R, Taylor F (1980) A broad spectrum artificial seawater medium for coastal and open ocean phytoplankton. J Phycol 16:28-35

Hutchins DA, DiTullio GR, Zhang Y, Bruland KW (1998). An iron limitation mosaic in the California upwelling regime. Limnol Oceanogr 43:1037-1054

Hutchins DA, Hare CE, Weaver RS, Zhang Y and 11 others (2002) Phytoplankton Fe limitation in the Humboldt Current and Peru Upwelling. Limnol Oceanogr 47:997-1011

Jeffrey WH, Mitchell DL (2001) Measurment of UVB induced DNA damage in marine planktonic communities. In: Paul $\mathrm{J}$ (ed) Methods in marine microbiology. Academic Press, New York, p 469-488

Jeffrey WH, Pledger RJ, Aas P, Hager S, Coffin RB, Von Haven R, Mitchell DL (1996) Diel and depth profiles of DNA photodamage in bacterioplankton exposed to ambient solar ultraviolet radiation. Mar Ecol Prog Ser 137: 293-304

Jeffrey WH, Kase JP, Wilhelm SW (2000) Ultraviolet radiation effects on bacterioplankton and viruses in marine ecosystems. In: de Mora S, Demers S, Vernet M (eds) Effects of UV radiation on marine ecosystems. Cambridge University Press, Cambridge, p 206-236

Kellogg CA, Paul JH (2002) Degree of ultraviolet radiation damage and repair capabilities are related to $\mathrm{G}+\mathrm{C}$ content in marine vibriophages. Aquat Microb Ecol 27:13-20

Minas HJ, Minas M (1992) Net community production in high nutrient-low chlorophyll waters of the tropical and Antarctic oceans-grazing vs iron hypothesis. Oceanol Acta 15: 145-162

Mitchell DL (1996) Radioimmunoassay of DNA damaged by ultraviolet light. In: Pfiefer G (ed) Technologies for detection of DNA damage and mutation. Plenum, New York, p 73-85

Mitchell DL (1999) Quantification of DNA photoproducts in mammalian cell DNA using radioimmunoassay. In: Henderson DS (ed) Methods in molecular biology, DNA repair protocols. Humana Press, Totowa, NJ, p 165-175

Morales CE, Hormazabel SE, Blanco JL (1999) Interannual variability in the mesoscale distribution of the depth of the upper boundary of the oxygen minimum layer off North Chile (18-24S): implications for the pelagic system and biogeochemical cycling. J Mar Res 57:909-932

Murray AG, Jackson GA (1993) Viral dynamics II: a model of the interaction of ultraviolet light and mixing processes on virus survival in seawater. Mar Ecol Prog Ser 102:105-114

Noble RT, Fuhrman JA (1997) Virus decay and its causes in coastal waters. Appl Environ Microbiol 63:77-83

Noble RT, Fuhrman JA (1998) Use of SYBR Green I for rapid epifluorescence counts of marine viruses and bacteria. 
Aquat Microb Ecol 14:113-118

Sambrook J, Fritsch E, Maniatis T (1989) Molecular cloning. Cold Spring Harbor Laboratory Press, Cold Spring Harbor, NY

Suttle CA, Chen F (1992) Mechanisms and rates of decay of marine viruses in seawater. Appl Environ Microbiol 58: 3721-3729

Suttle CA, Chan AM, Chen F, Garza DR (1993) Cyanophages and sunlight: a paradox. In: Guerrero R, Pedros-Alio C (eds) Trends in microbial ecology. Spanish Society for Microbiology, Barcelona, p 303-308

Weinbauer MG, Wilhelm SW, Suttle CA, Garza DR (1997) Photoreactivation compensates for UV damage and restores infectivity to natural marine viral communities. Appl Environ Microbiol 63:2200-2205

Weinbauer MG, Wilhelm SW, Suttle CA, Pledger RJ, Mitchell DL (1999) Sunlight-induced DNA damage and resistance in natural viral communities. Aquat Microb Ecol 17: 111-120

Wilhelm SW, Poorvin L (2001) Quantification of algal viruses in marine samples. In: Paul J (ed) Methods in microbiology. Academic Press, London, p 53-66

Editorial responsibility: Gunnar Bratbak, Bergen, Norway
Wilhelm SW, Suttle CA (1999) Viruses and nutrient cycles in the sea. BioScience 49:781-788

Wilhelm SW, Suttle CA (2000) Viruses as regulators of nutrient cycles in the sea. In: Bell CR, Brylinsky M, JohnsonGreen P (eds) Proc 8th Int Symp Microb Ecol. Atlantic Canada Society for Microbial Ecology, Halifax, p 551-556

Wilhelm SW, Weinbauer MG, Suttle CA, Jeffrey WH (1998a) The role of sunlight in the removal and repair of viruses in the sea. Limnol Oceanogr 43:586-592

Wilhelm SW, Weinbauer MG, Suttle CA, Pledger RJ, Mitchell DL (1998b) Measurements of DNA damage and photoreactivation imply that most viruses in marine surface waters are infective. Aquat Microb Ecol 14:215-222

Wilhelm SW, Jeffrey WH, Suttle CA, Mitchell DL (2002) Estimation of biologically damaging UV levels in marine surface waters with DNA and viral dosimeters. Photochem Photobiol 76:268-273

Wommack KE, Colwell RR (2000) Virioplankton: viruses in aquatic ecosystems. Microbiol Mol Biol Rev 64:69-114

Wommack KE, Hill RT, Muller TA, Colwell RR (1996) Effects of sunlight on bacteriophage viability and structure. Appl Environ Microbiol 62:1336-1341

Submitted: September 5, 2002; Accepted: November 25, 2002 Proofs received from author(s): January 20, 2003 